\title{
Enhancing Campus Cyber Security through a Class with Combination of Computer Ethics Videos and Logical Thinking
}

\author{
Takashi Yamanoue \\ Fukuyama University \\ Fukuyama, Hiroshima \\ 729-0292, Japan \\ +81-84-936-2111 \\ yamanoue@fuip.fukuyama- \\ u.ac.jp
}

\author{
Noboru Nakamichi \\ Fukuyama University \\ Fukuyama, Hiroshima \\ 729-0292, Japan \\ +81-84-936-2111 \\ nakamiti@fuip.fukuyama- \\ u.ac.jp
}

\author{
Kunihiko Kaneko \\ Fukuyama University \\ Fukuyama, Hiroshima \\ 729-0292, Japan \\ +81-84-936-2111 \\ kaneko@fuip.fukuyama-u.ac.jp
}

\begin{abstract}
Further trials in a class for enhancing campus cyber security are discussed. The class uses computer ethics video clips and logical thinking teaching material. Rubrics (evaluation criteria) are shown to students and their activity in the class is evaluated by the rubrics. The video clips are designed for promoting discussion, and the logical thinking teaching material shows ways of discussion in a group. They should raise the retention rate of the class according to the "Learning Pyramid".
\end{abstract}

\section{CCS Concepts}

- Security and privacy Human and societal aspects of security and privacy

- Social and professional topics Computing literacy

\section{Keywords}

Cyber security; Education; Video clips; Logical thinking; Rubrics

\section{INTRODUCTION}

Campus cyber security is one of the most important and one of the toughest subjects for ICT managers in universities and colleges today. It is relatively easy to control the security of technical aspect of a campus using technologies such like firewalls, IDSs, IPSs and so on. However, it is hard to control behavior of people in a university or a college. Their cooperation is essential for keeping the cyber security of a university or a college. In order to have their cooperation, ICT managers are having various ways of education for them.

According to the "Learning Pyramid" [1] by Edgar Dale, the learning retention rate of audio-visual material is $20 \%$. It is much better than the rate of a lecture, which is $5 \%$. So a group in Japan, including one of the authors of this paper, have made "Computer ethics video clips" Error! Reference source not found. and updated them for enhancing the human

Permission to make digital or hard copies of all or part of this work for personal or classroom use is granted without fee provided that copies are not made or distributed for profit or commercial advantage and that copies bear this notice and the full citation on the first page. Copyrights for components of this work owned by others than ACM must be honored. Abstracting with credit is permitted. To copy otherwise, or republish, to post on servers or to redistribute to lists, requires prior specific permission and/or a fee. Request permissions from Permissions@acm.org.

SIGUCCS '16, November 06-09, 2016, Denver, CO, USA

(C) 2016 ACM. ISBN 978-1-4503-4095-3/16/11 ..\$15.00

DOI: http://dx.doi.org/10.1145/2974927.2974939 aspect of campus cyber security for more than ten years Error! Reference source not found.. These video clips became one of the indispensable teaching materials for many universities in Japan.

In order to have a good discussion in a computer ethics class, we have designed a new course with "Logical thinking" Error! Reference source not found. or "Critical thinking" teaching material. We use the teaching material of critical thinking Error! Reference source not found., which is available from the Information-technology Promotion Agency (IPA), Japan. It is based on the "Learning Pyramid," and discussions in a group are encouraged in the material.

We are having the class now. This paper shows the outline of the class in section two, an example of one day's class and students' feedback in section three, related work in section four, and the conclusion in section five

\section{OUTLINE OF THE CLASS}

\subsection{Syllabus}

In order to enhance cyber security in a campus, every member of the campus should take a class for cyber security. As an intermediate step to realize this, we have planned to have an introductory information processing class (IP1 class) with cyber security and computer ethics for freshmen of computer science. For other members in our university, brochures for keeping campus cyber security were made and distributed to everyone in our university. In addition to this, the video clips in this paper can be viewed by all members in our university at specific PCs on our campus.

The class in this paper was the place for learning a part of office software by freshmen of computer science. Many of the students are used to using office software now. So we have changed the main theme of this class from learning office software to learning cyber security and computer ethics.

There are 41 students in this class. They were divided into ten groups to have group discussions. One group consists of three to five students.

We have made the syllabus of the IP1 class as follows.

- Outline of the class: Teaching knowledge and techniques of basic cyber security, computer ethics, and using a presentation software (PowerPoint). Training the attitude toward them. Having group practices of them using IT tools. Such knowledge, techniques and attitude will be useful in all 
of learning, the graduation project in our university, getting jobs, and working after graduation.

- Objectives of the class: Learn the knowledge, techniques of the above and attitude toward them.

- Course Schedule: Shown in Table 1.

- Grading Procedure: Grading every practice of each day of class.

Table 1. Course Schedule

\begin{tabular}{|c|c|}
\hline Day & Contents \\
\hline 1 & $\begin{array}{l}\text { Outline of this class. Turn on/Turn off the PC. } \\
\text { Login/Logout. ID/Password. Basic operation of } \\
\text { Windows OS. Basic operation of a Web browser. How } \\
\text { to use the university's student management system. } \\
\text { Initial settings of the student management system. }\end{array}$ \\
\hline 2 & How to use PowerPoint software. Making groups. \\
\hline 3 & Outline of "Logical Thinking." \\
\hline 4 & $\begin{array}{l}\text { "Why tree" of logical thinking and drawing the "why } \\
\text { tree" using SmartArt graphic feature in PowerPoint. }\end{array}$ \\
\hline 5 & $\begin{array}{l}\text { "How tree" of logical thinking and drawing the "how } \\
\text { tree" using SmartArt graphic feature in PowerPoint. }\end{array}$ \\
\hline 6 & Importance of a password. \\
\hline 7 & $\begin{array}{l}\text { Know-how for preparing for losing private } \\
\text { information, Losing private information by using a } \\
\text { reward card. }\end{array}$ \\
\hline 8 & Privacy and GPS. Where is the data? \\
\hline 9 & $\begin{array}{l}\text { Flooding of complaints because of phishing. Using } \\
\text { Internet services safely. }\end{array}$ \\
\hline 10 & $\begin{array}{l}\text { Responsibility and privacy of seminar activity. A } \\
\text { community in which it is difficult to refuse to } \\
\text { participate. }\end{array}$ \\
\hline 11 & $\begin{array}{l}\text { Taking pictures and uploading them to a Web site } \\
\text { without permission. It is difficultto withdraw the } \\
\text { statement on the Internet. }\end{array}$ \\
\hline 12 & $\begin{array}{l}\text { It is No Good to copy an item from the Web and paste } \\
\text { it to your paper. It is dangerous to cheat to write a } \\
\text { paper. }\end{array}$ \\
\hline 13 & $\begin{array}{l}\text { Is it possible to introduce a mail in a blog? Is it } \\
\text { possible to use a smartphone while doing something } \\
\text { else? }\end{array}$ \\
\hline 14 & A smart phone knows everything. \\
\hline 15 & Concluding the class. \\
\hline
\end{tabular}

In day one, students learn the basic features to use PCs and Web sites of our university. In day two, they learn the use of PowerPoint software. However almost all of them said they have used the software. From day three to day five, students learn the basic features of logical thinking. From day six to day 14, they learn cyber security and computer ethics using the computer ethics video clips, logical thinking, PowerPoint software and LMS
(Learning Management System) of our university. In order to enhance students' activity in each class, rubrics (evaluation criteria) are shown to students and students are evaluated by the rubrics.

\subsection{Preparation}

Day one through day five of the class are preparation for the rest of the class. Students learn tools for understanding and giving solutions of problems, which are related to cyber security and computer ethics, during this term. Their main tools are logical thinking. The SmartArt graphic feature of PowerPoint software is used for assisting the logical thinking.

Logical thinking includes the following elements.

- Ways of thinking

1) Induction and deduction

2) MECE (mutually exclusive and collectively exhaustive)

3) Zero base thinking

4) Hypothetical thinking

- Tools

1) Logic tree

2) Pyramid structure

3) Matrix

- Ways of proceeding

1) Card brain storming

2) Facilitation

\subsection{Main Classes}

Main classes, which teach cyber security and computer ethics, start from day six and continue until day 14. Each of the main classes proceeds as follows

1) The MC (master of ceremonies) and the secretary are selected in each group of students. We have asked students to change the MC every day of the class in order to let every member in our class have the experience of becoming MC.

2) Students see the episode (problem) part of a video clip.

3) Rubrics are shown to all students.

4) Each group of students starts discussion about why the problem happened and how to cope with the problem. They use elements of the logical thinking.

5) Each group writes the why tree to analyze the problem and writes the how tree to cope with the problem using the SmartArt function of PowerPoint software.

6) They submit the two trees to the LMS as the result of the discussion.

7) Students see the explanation part of the video clip.

8) Students evaluate their activity by themselves using the rubrics. The quiz function of the LMS is used for this evaluation.

\subsection{Rubrics}

Students are expected to acquire not only knowledge of cyber security and computer ethics but also the ability to co-operate with 
others and to think more deeply using various tools. In order to realize this and evaluate this, we use the following rubrics.

- Your contribution to the group

$\begin{array}{ll}\text { MC } & 5 \text { points } \\ \text { Secretary } & 4 \text { points } \\ \text { Support the MC } & 3 \text { points }\end{array}$

- Your contribution to the group work to make the why tree.

More than or equal to three ideas (cards) 5 points

Two ideas (cards) 4 points

One idea (card) 3 points

- Number of layers of the why tree of your group

$\begin{array}{ll}\text { More than or equal to four } & 5 \text { points } \\ \text { Three } & 4 \text { points }\end{array}$

Two 3 points

- Number of items of the why tree of your group

More than or equal to $20 \quad 5$ points

Between 10 to $19 \quad 4$ points

Between 5 to 9 points

- Your contribution to the group work to make the how tree.

More than or equal to three ideas (cards) 5 points

Two ideas (cards)

4 points

One idea (card)

3 points

- Number of layers of the how tree of your group

More than or equal to four 5 points

Three 4 points

Two 3 points

- Number of items of the how tree of your group

More than or equal to $20 \quad 5$ points

Between 10 to $19 \quad 4$ points

Between 5 to 9 points

\section{A TYPICAL DAY OF THE CLASS}

We show day six of the class as an example of the class. The day of the class proceeded as follows.

1) The MC (master of ceremonies) and the secretary were selected in each group of students.

2) Students saw the episode (problem) part of a video clip. We have used the video of "More than Ever! The Importance of Passwords." The duration of the episode part of this video is $5 \mathrm{~min} .59 \mathrm{sec}$. Figure 1 shows a scene from the video.
The following is the outline of the episode part of this video clip.

"Kento (a male student) saw the news of leaking the ID and the password. This news upset him because he was using the ID for various services. However, he did not have trouble because he had changed the password of the ID at the official Web site of the ID. Masami (a female student) used the same password for various services. She changed the password of the leaked site and felt at ease. But she has not changed the password of other services because she thought that they are different services from the leaked site. Her ID of one of these sites has been used by some others and her money was used for music downloading."

Ten years ago, there was a common sense that passwords should be memorized and should not be noted on a piece of paper. However, ten years later, any short password can be uncovered easily by recent computing power. So passwords should be long enough to endure such computing power. It is hard to memorize such long passwords precisely in the brain of most people. In order to cope with this problem, the explanation part of the clip of "More than Ever! The Importance of Passwords" suggests a way to note long passwords on a piece of paper

Hookups of services on the Internet were not so common ten years ago. On the other hand, hookups of services are common today. Any of the services of a hookup can be used by entering only one pair of ID and password today. When the password of a hookup of services on the Internet is leaked, all services of the hookup can be intruded upon by other people. On-line payment is also common today.

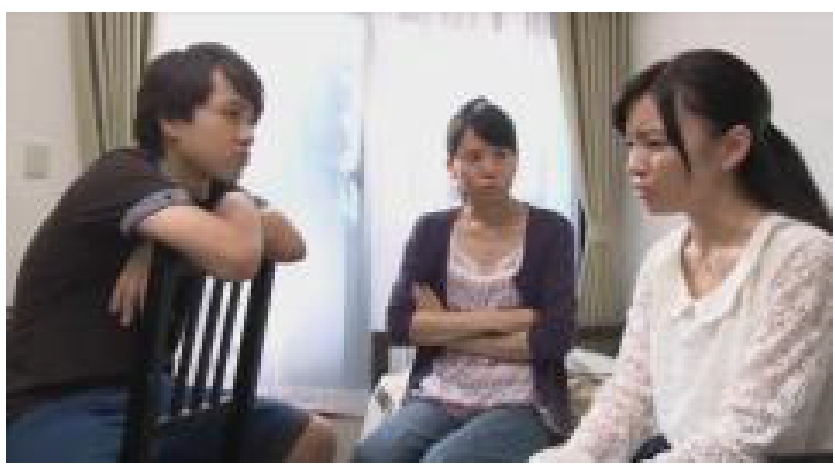

Figure 1. A scene of the video of "More than Ever! The Importance of Passwords"

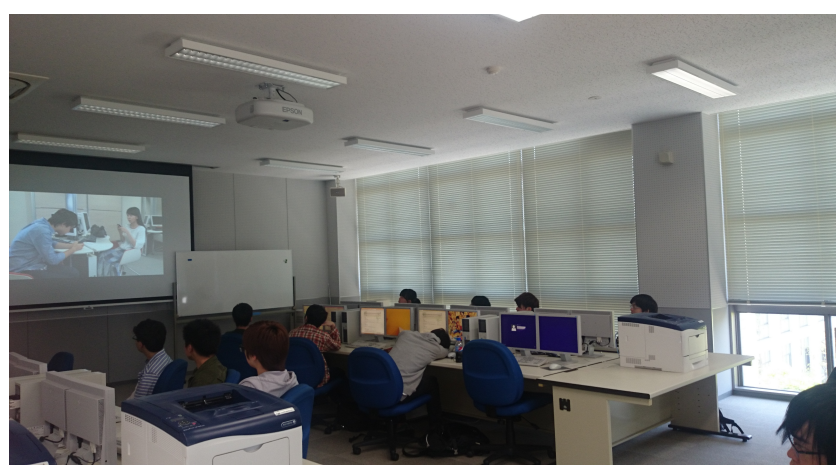

Figure 2. Students seeing the video in class 


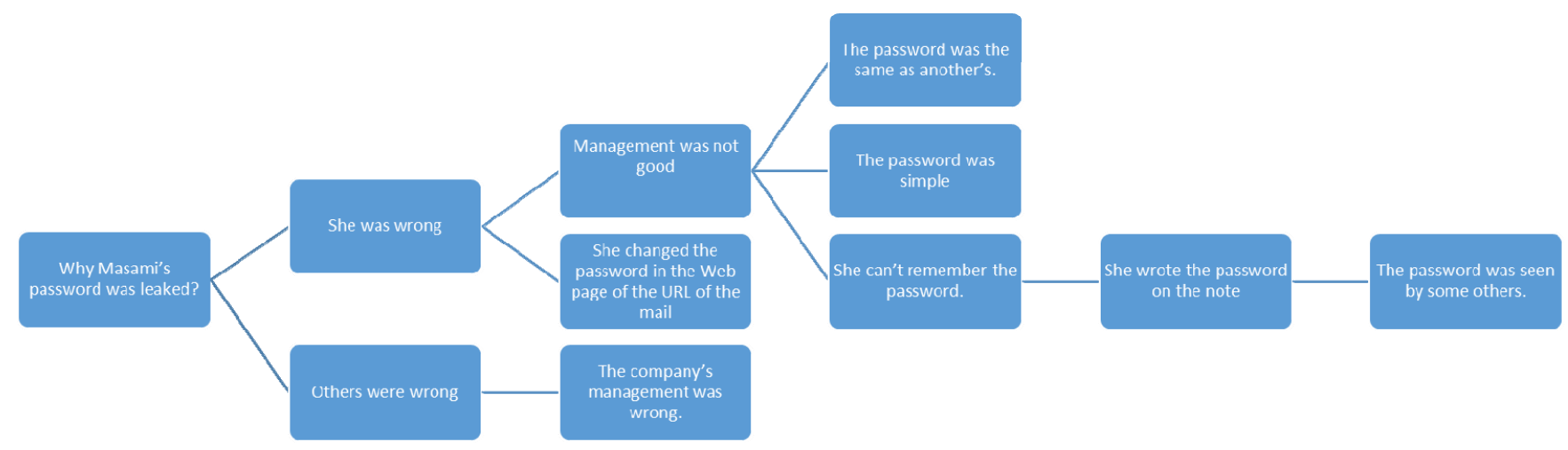

Figure 3. Why tree of a group in the class.

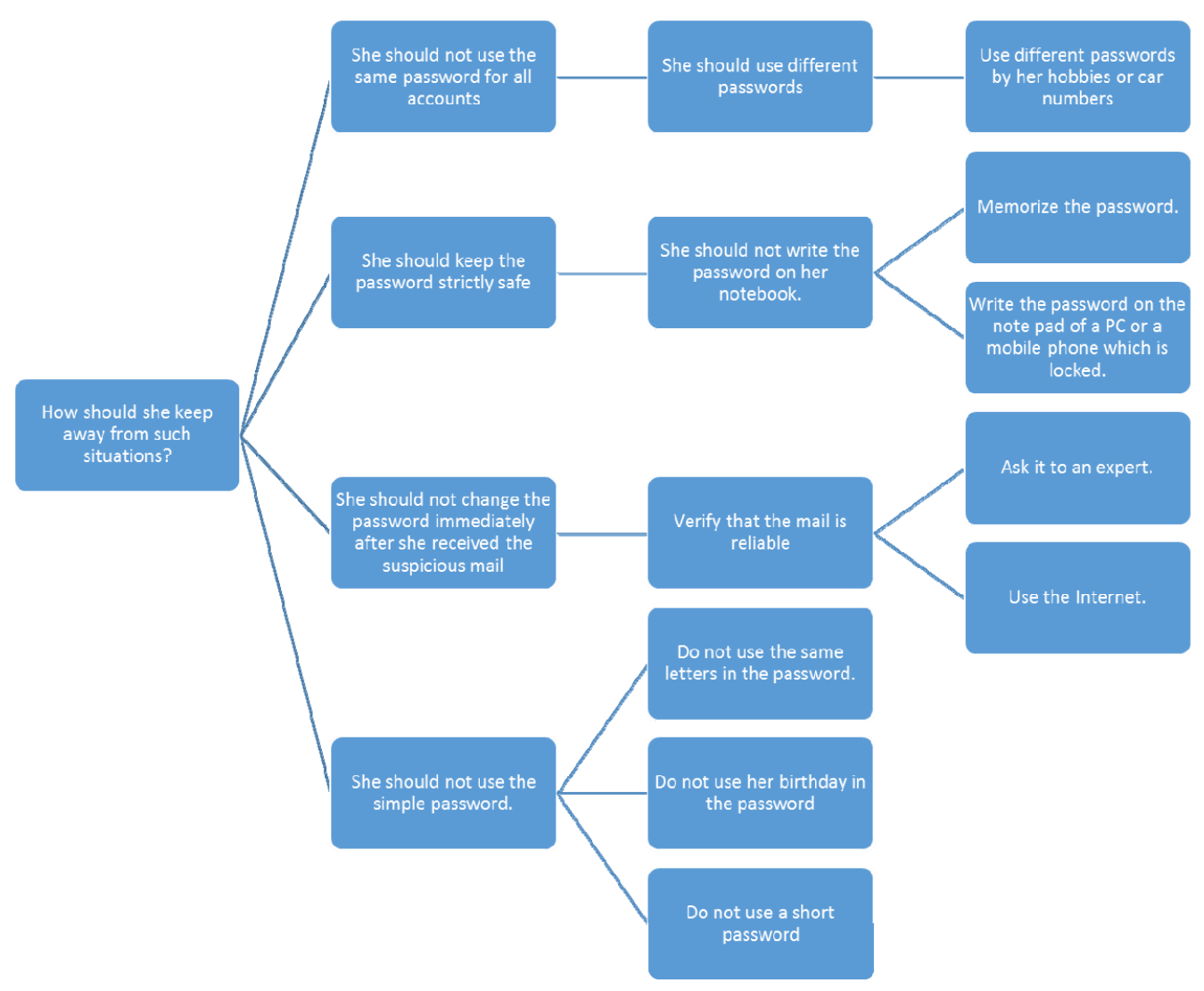

Figure 4. How tree of a group in the class.

If a user was using the same password for a service with online payment and a service without on-line payment, and if the password of the service without on-line payment was leaked, the password of the service with on-line payment can also be leaked and malicious people may steal money of the user. The clip of "More than Ever! The Importance of Passwords" also includes topics of such situations. We expected that some groups of students would deduce such ideas.
3) After viewing the episode part of the video clip, rubrics were shown to students.

4) Then, students had group discussions for making the why tree and the how tree.

The root node of the why tree was "Why Masami's password was leaked?" The root node of the how tree was "How should she keep away from such situations?" 
One group of two students was using the SmartArt graphic feature of PowerPoint directly. Other groups were using cards before writing the trees.
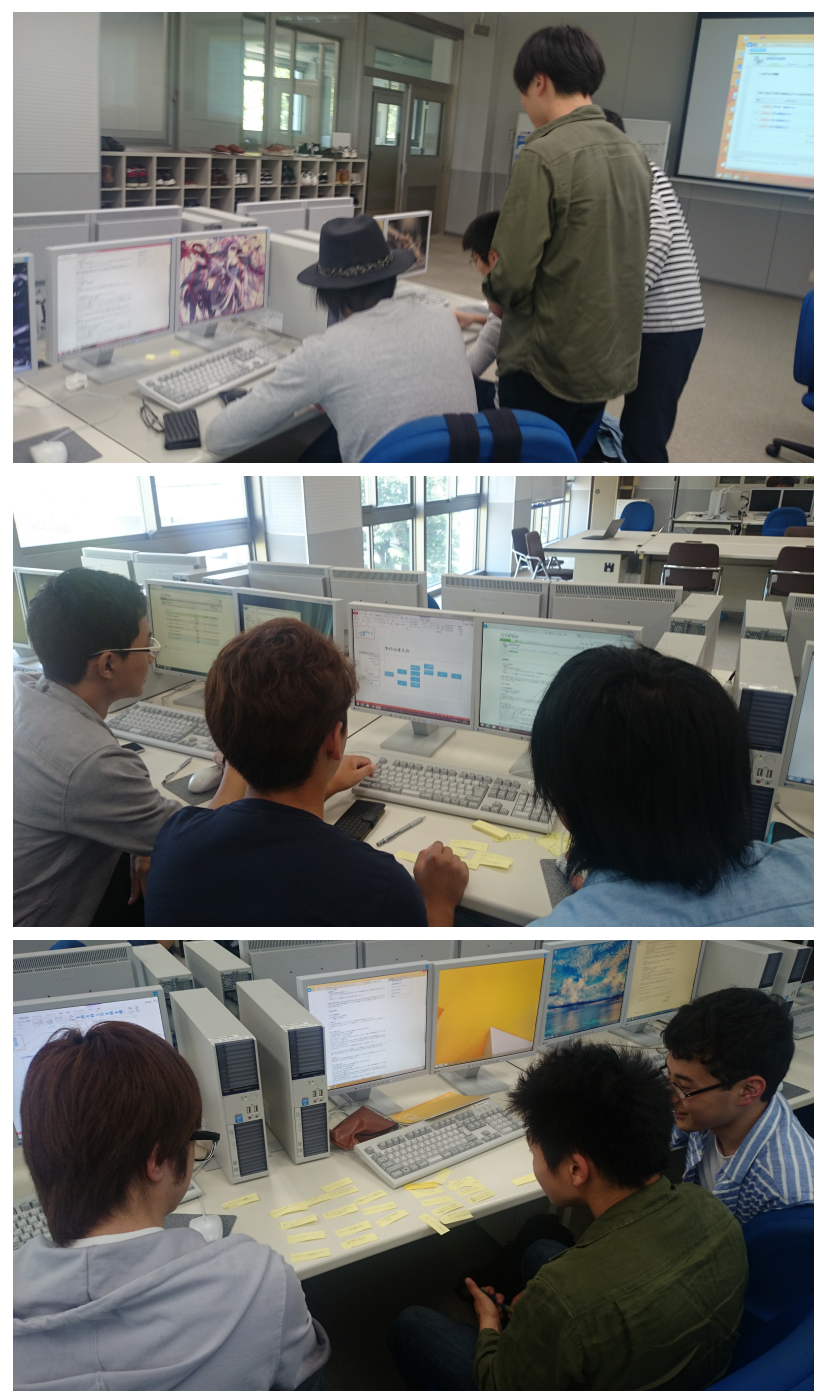

Figure 5. Group discussion

5) After the discussion term, each group wrote the why tree and the how tree.

6) Each group has submitted the why tree and the how tree to the LMS. Figure 3 is an example of a why tree and the Figure 4 is a how tree of a group in this class. Figure 5 shows pictures of the discussion.

The node "The password was the same as another's" in the why tree, shows the reason of the password leak in the video. Almost all groups have reached this reason because the episode part gives viewers the suggestion. Students of the group show possible reasonable reasons--not only the reason in the video but also others--in the why tree. Students of other groups also show many reasonable reasons.

The node "Write the password on the note pad of a PC or a mobile phone which can be locked" in the how tree, is a reasonable solution which solves the conflicting conditions of "a password should be long enough" and "she should not write the password on the note."

Unfortunately, there were many nodes of "She was off guard" or similar words, in a leaf node of why trees in other groups. These were not wrong, but we expected that students would think more deeply and show the reason of "why she was off guard."

7) Students evaluated their activity by themselves using the rubrics. The quiz function of the LMS is used for this evaluation. Table 2 shows the quantification of the discussion for making the why tree which was acquired by evaluation using the rubrics. Table 3 shows the quantification of the discussion for making the how tree which was acquired by evaluation using the rubrics.

These rubrics were also useful to make the class active. Many groups tried to get a high score, so students tried to give many ideas in the group discussion. Many ideas may contain many good ideas.

8) Students saw the explanation part of the video clip.

Table 2. Quantification of the discussion for making the why tree and its result.

Number of all cards of the card brain 150 storming in the group discussion for making the why tree in the class.

\begin{tabular}{|c|c|}
\hline $\begin{array}{l}\text { Average number of cards of one student in the } \\
\text { group discussion }\end{array}$ & 4 \\
\hline $\begin{array}{l}\text { Total number of nodes of the why tree in this } \\
\text { class }\end{array}$ & 123 \\
\hline Average number of nodes of one why tree & 12.3 \\
\hline Smallest number of nodes of the why tree & 8 \\
\hline Largest number of nodes of the why tree & 20 \\
\hline Average height of the why tree & 4.5 \\
\hline Least height of the why tree & 3 \\
\hline Greatest height of the why tree & 6 \\
\hline
\end{tabular}

Table 3. Quantification of the discussion for making the how tree and its result.

Number of all cards of the card brain 153 storming in the group discussion for making the how tree in the class.

Average number of cards of one student in the $\quad 4.6$ group discussion

Total number of nodes of the how tree in this 134 class

\begin{tabular}{lc}
\hline Average number of nodes of one how tree & 13.4 \\
\hline Smallest number of nodes of the how tree & 9 \\
\hline Largest number of nodes of the how tree & 20 \\
\hline Average height of the how tree & 4 \\
\hline Least height of the how tree & 3 \\
\hline Greatest height of the how tree & 5 \\
\hline
\end{tabular}


We obtained the numbers in Table 2 and Table 3 from the selfevaluation of the rubrics in the LMS of our university. This way realizes the visualization and quantification of activity of group work. It also realizes the visualization and quantification of how the group thinks deeply. These visualizations and quantifications can be useful to improve this class. Figure 6 shows a screenshot of a part of the self-evaluation of the rubrics in the LMS.

The following statements are examples of students' feedback of this class. From the feedback, our aim of enhancing cyber-security of our campus by enhancing users' consciousness of cybersecurity seems to be achieved.

- "I was thinking, the discussion is boring before. However, the discussion was very fun after the start."

- "At the first, the group discussion was awkward. However, on the way of the discussion, co-operation in the group has been developed."

- "This class was very useful".

- "I was re-using the same password for many accounts. I would like to change them."

\section{RELATED WORK}

There is the following related work. However, we could not find out a cyber security class which combines video clips, logical thinking, and rubrics.

\subsection{Thinking in Computer Ethics Education}

Jones said, “... it is part of the task of computer ethics to define, develop, and modify existing moral theory when existing theory is insufficient or inadequate in light of new demands generated by new practices involving technology." [2] He said, in order to cope with such changes, thinking is important in computer ethics education. We have shown a way for thinking through group discussion.

\subsection{Logical Thinking in Computer Science Classes}

References [6], [7], [8], and [9] are cases for using logical thinking for computer science education, not for cyber security.

Your contribution to the group works to make the why tree.

・Why Tree 作成時あなたはブレインストーミ゙グのカードを何枚書きましたか?

1.5

More than or equal to three ideas (cards)? 5 points

それは3枚以上ですか? (はい、の場合5)

1.6

○はい○いえ

いいえの場合、More than or equal to two ideas (cards)?

4 points

あなたはブレインストーミングのカードを2枚書きましたか? (はい、の場合4)

1.7

○はい○いえ

いいえの場合、One idea (card)? 3 points

あななはブレイインストミングのカードを1枚は書きましたか? (はい、の場合3)

1.8

○はい○いいえ

Number of layers of the why tree of your group?

・各班で作成したWhy Tree (なぜパスワードが漏れたか?)につい、

階層の数(一番上の「なぜパスワードが漏れたか?」」含みます)は、何階層でたか?

1.9

More than or equal to four?

階層は4階層以上ありますか? (はい、の場合5)

.... 5 points

1.10

○はい○いい

Figure 6. Screenshot of a part of the self-evaluation of the rubrics in the LMS of our university 


\subsection{Rubrics and Computer Ethics}

The reference [10] shows grading essays of a computer ethics class using rubrics. Rubrics were useful for decreasing ambiguity of grading essays in the reference. Our rubrics also help decrease ambiguity of grading group discussion and grading why trees and how trees.

\section{CONCLUSION}

The purpose of the class in this paper is enhancing the human aspect of the campus cyber security. We expect that students of this class understand the importance of cybersecurity deeply and keep knowledge and techniques on cybersecurity in their minds for long time. We have combined various ways such as computer ethics video clips, logical thinking and rubrics to realize our expectation.

We could not judge the new class in this paper against previous classes, because we do not have quantified data of previous classes. However, we have quantified data of the cyber security class now. We can compare this class with future classes, and this can improve the cyber security of our campus.

\section{ACKNOWLEDGEMENT}

We thank Mr. Katagiri and Mr. Nakamura who are co-teachers of the class of information processing basics, the group who produced the computer ethics video clips, IPA (Information technology Promotion Agency, Japan) who allows us to use the teaching material of critical thinking. A part of this research was supported by JSPS KAKENHI Grant Number JP16K00197.

\section{REFERENCES}

[1] Dale, E. 1946. Audio-Visual Method in Teaching. The Dryden Press.

[2] Jones, A. 2004. Technology: Illegal, Immoral, or Fattening? In Proceedings of the 32nd Annual ACM SIGUCCS Conference on User Services (Baltimore, Maryland, US. 1013 Oct. 2004). ACM, New York, NY, 305-309. DOI=http://doi.acm.org/10.1145/1027802.1027872

[3] Yamanoue, T., Nakanishi, M., Nakamura, A., Fuse, I., Murata, I., Fukada, S., Tagawa, T., Takeo, T., Okabe, S., and Yamada, T. 2005. Digital Video Clips Covering Computer Ethics in Higher Education. In Proceedings of the 33nd Annual ACM SIGUCCS Conference on User Services (Monterey, California, US, 6-9 Nov. 2005). ACM, New York, NY. 456-461. DOI=http://doi.acm.org/10.1145/1099435.1099536
[4] Yamanoue, T., Fuse, I., Okabe, S., Nakamura, A., Nakanishi, M., Fukada, S., Tagawa, T., Tatsumi, T., Murata, I, Uehara, T., Yamada, T., Ueda, H. 2014. Computer Ethics Video Clips for University Students in Japan from 2003 until 2013, In Proceedings of the 38th Annual International Computer Software \& Applications Conference (COMPSAC2013/ADMNET WS), (Västerås, Sweden, 2125 Jul. 2014). IEEE, NJ, 96-101. DOI $=10.1109 /$ COMPSACW .2014 .21

[5] Minto, M. 2008. The Pyramid Principle: Logic in Writing and Thinking (Financial Times Series). Prentice Hall, NY.

[6] Kawai, H., Takayama, F., Anzai, T., Manome, T. and Yoshida, H. 2003. Objectives and features of e-learning oriented programming courseware for freshmen, Distributed Computing Systems Workshops, Proceedings. 23rd International Conference on. IEEE, NJ. 616-621. DOI=10.1109/ICDCSW.2003.1203621

[7] Iwane, N. and Saito, N. 2013. Reuse of mathematical problems and answers with e-learning system, Humanitarian Technology Conference (R10-HTC), 2013 IEEE Region 10, (Sendai, Japan, 26-29 Aug. 2013). IEEE, NJ. 227-231. DOI $=10.1109 /$ R10-HTC. 2013.6669046

[8] Muller, O., and Rubinstein, A., 2011. Work in progress Courses dedicated to the development of logical and algorithmic thinking, 2011 Frontiers in Education Conference (FIE), (Rapid City, SD, US. 2011). IEEE, NJ. F3G-1-F3G-3. DOI=10.1109/FIE.2011.6142846

[9] Parham, J. R.. 2003. An assessment and evaluation of computer science education. Journal of Computing Sciences in Colleges. Vol. 19, Issue 2. CCSC. 115-127.

[10] Moskal, B., Miller, K., Smith King, L. A. 2002. Grading essays in computer ethics: rubrics considered helpful. In Proceedings of the 33rd SIGCSE Technical Symposium on Computer Science Education (SIGCSE '02). (Covington, KY, USA, 26 Feb. - 2 Mar. 2002). ACM, New York, NY. 101105 .

DOI=http://doi.acm.org/10.1145/563517.563380

[11] Educational contents for development of personal skill, https://www.jsee.or.jp/?action=common_download_main\&u pload_id=951 (in Japanese) 